\title{
Regulation of Bcl-2-family proteins in myeloma cells by three myeloma survival factors: interleukin-6, interferon-alpha and insulin-like growth factor 1
}

\author{
M Jourdan' ${ }^{1}, \mathrm{~J}$ De $\operatorname{Vos}^{1}, \mathrm{~N}$ Mechti ${ }^{1}$ and B Klein ${ }^{*, 1}$ \\ 1 INSERM U475 and Unit for Cellular Therapy, CHU Montpellier, 34197 \\ Montpellier, France \\ * Corresponding author: B Klein, INSERM U475, 99 rue Puech Villa, 34197 \\ Montpellier, France. Tel: 33-(0)4 6763 61 25; Fax: 33-(0)4 670418 63; \\ E-mail: klein@montp.inserm.fr
}

Received 5.6.00; revised 24.7.00; accepted 7.8.00

Edited by $\mathrm{G}$ Ciliberto

\begin{abstract}
As survival regulation is a key process in multiple myeloma biology, we have studied the Bcl-2 family proteins that can be regulated by three myeloma cell survival factors: interleukin- 6 (IL-6), interferon- $\alpha$ (IFN- $\alpha$ ) and insulin-like growth factor (IGF1). Eleven myeloma cell lines, whose survival and proliferation are dependent on addition of IL-6, variably expressed 10 antiapoptotic or pro-apoptotic proteins of the Bcl-2-family. When myeloma cells from four cell lines were IL- 6 starved and activated with IL- 6 or IFN- $\alpha$, we observed that only Mcl-1 expression was up-regulated with myeloma cell survival induction. Nor was obvious regulation of these 10 proapoptotic or anti-apoptotic proteins found with IGF-1, another potent myeloma cell survival factor. Our results indicate that the myeloma cell survival activity of IL-6 linked to Bcl-xL regulation cannot be generalized and emphasize that Mcl-1 is the main target of IL- 6 and IFN- $\alpha$ stimulation. However, other changes in the activity of the Bcl-2 protein family or other apoptosis regulators must be identified to elucidate the IGF-1 action mechanism. Cell Death and Differentiation (2000) 7, $1244-1252$.
\end{abstract}

Keywords: myeloma; IL-6; IGF; apoptosis

Abbreviations: $\mathrm{BH}, \mathrm{Bcl}-2$ homology domain; $\mathrm{BSA}$, bovine serum albumin; HMCL, human myeloma cell line; IGF-1, insulin-like growth factor 1; IL-6, interleukin-6; IFN- $\alpha$, interferon-alpha; PTP, permeability transition pore

\section{Introduction}

Multiple myeloma is a B cell neoplasia characterized by the bone marrow accumulation of clonal malignant plasma cells. In the majority of patients, tumor cells do not proliferate or proliferate very slowly. ${ }^{1,2}$ Thus, a long survival of myeloma cells can explain the tumor growth.
Interestingly, normal plasma cells can also survive for several months in vivo. ${ }^{3}$ Medullary stromal cells are probably critical in promoting this survival of normal or malignant plasma cells in vivo. Indeed, normal plasma cells generated in vitro rapidly die but medullary stromal cells can trigger their survival in vitro. ${ }^{4}$ Malignant plasma cells from patients with chronic disease rapidly apoptose as soon as they are separated from stromal cells. ${ }^{5}$ However, the survival factors produced by stromal cells are poorly identified. IL- 6 and cytokines of the IL- 6 family ${ }^{6-8}$ are important growth factors but are not sufficient to prevent apoptosis of purified myeloma cells. ${ }^{5}$ IFN- $\alpha^{9,10}$ and IGF$1^{11-13}$ are also myeloma cell survival factors.

Induction of apoptosis involves a family of death proteases, called caspases, which are activated in a proteolytic cascade to execute the cell death program. Caspase activation is controlled by a growing family of antiapoptotic and pro-apoptotic proteins (see Gross et al. ${ }^{14}$ and Adams et al. ${ }^{15}$ for review). These proteins possess one to four conserved motifs, called $\mathrm{Bcl}-2$ homology domains $(\mathrm{BH}-$ 1 to $\mathrm{BH}-4)$ and may form homo- or hetero-dimers. In numerous cells, the survival activity of growth factors is determined in part by the relative concentrations of pro- and anti-apoptotic Bcl-2-family members. The most widely studied anti-apoptotic proteins are $\mathrm{Bcl}-2$ and $\mathrm{Bcl}-\mathrm{xL}$ with four $\mathrm{BH}$ domains and a transmembrane domain that allows their location to the outer mitochondrial membrane. They are thought to regulate the permeability transition pore (PTP) and block both the mitochondrial exit of cytochrome $C$ and the activation of procaspase 9 by APAF-1cytochrome $c$ complexes. Like Bcl-2, $\mathrm{Mcl}-1$ has four $\mathrm{BH}$ domains and a transmembrane domain and may function as $\mathrm{Bcl}-2$ and $\mathrm{Bcl}-\mathrm{xL}$, but this has yet to be proved. ${ }^{14} \mathrm{Bag}-1$ does not belong to the Bcl-2-family proteins but has an antiapoptotic activity probably by increasing Bcl-2, Bcl-xL or Mcl-1 activity. ${ }^{16} \mathrm{Bfl}-1 / \mathrm{A} 1$ has four $\mathrm{BH}$ domains but no transmembrane domain. There are also numerous proapoptotic proteins. The most thoroughly studied are Bax and Bak, which have three $\mathrm{BH}$ domains and a transmembrane domain and are translocated to the mitochondrial membrane when an apoptotic signal is delivered. They are believed to deliver apoptosis by opening the PTP, thus affecting the electrical potential gradient of the mitochondria and favoring cytochrome $c$ release. They can also dimerize with anti-apoptotic proteins, thus encouraging PTP to open and APAF-1 to activate. Roughly eight pro-apoptotic proteins have only a $\mathrm{BH} 3$ domain with or without a transmembrane domain. Bid and Bad are the most widely studied and are mostly competitors of anti-apoptotic proteins. $^{14,15}$

Currently, only a few members of the Bcl-2 family have been studied in myeloma cells. Several groups have shown 
a high expression of $\mathrm{Bcl}-2$ in myeloma cells lines, in primary myeloma cells as well as in normal plasma cells. ${ }^{17,18}$ This high $\mathrm{Bcl}-2$ expression in myeloma cells did not correlate with patient survival ${ }^{19,20}$ and even inversely correlated with the plasma cell proliferation in vivo. ${ }^{21} \mathrm{IL}-6$, a major myeloma cell survival factor, did not affect $\mathrm{Bcl}-2$ expression. ${ }^{22-24} \mathrm{Bcl}-\mathrm{xL}$ was also expressed in a majority of myeloma cell lines or primary myeloma cells. ${ }^{20,21}$ In the U266 and MDN myeloma cell lines, an increase in Bcl-xL expression was recently shown to be associated with myeloma cell survival induced by IL-6. ${ }^{24,25}$ However, IL-6 did not regulate $\mathrm{Bcl}-\mathrm{xL}$ expression in the RPMI 8226 myeloma cell line although it blocked apoptosis induced by dexamethasone in this cell line. ${ }^{26}$ Recently, Puthier et al. found that IL- 6 regulated the $\mathrm{Mcl}-1$ anti-apoptotic protein in the MDN IL-6-dependent cell line. ${ }^{24}$ Among the proapoptotic proteins, Bax expression was documented in primary myeloma cells ${ }^{20}$ and in myeloma cell lines. ${ }^{22} \mathrm{Bad}$ was weakly expressed in myeloma cell lines and its phosphorylation by IL-6 was not detected. ${ }^{27}$ Finally, BclXS was not detected in myeloma cells. ${ }^{20,21}$

Study of the mechanisms controlling malignant plasma cell survival is limited by the difficulty in obtaining a sufficient number of tumor cells from patients. For this reason, the few studies dealing with this topic have used either cells or cell lines obtained from patients with terminal disease and extramedullary proliferation. From these patients, we obtained several myeloma cell lines whose survival and proliferation require adding exogenous IL-6. These cell lines very closely resemble the myeloma stem cells that are present in patients with terminal disease, as previously discussed. ${ }^{28}$ Using these cell lines, we have shown that IFN- $\alpha$ is also a potent survival factor ${ }^{9}$ and that IGF-1 is a survival and proliferation factor. ${ }^{13}$ In the current study, we investigated the expression of $10 \mathrm{Bcl}$-2-family proteins in 11 myeloma cell lines whose survival requires adding an exogenous cytokine. We also studied how IL-6, IFN- $\alpha$ or IGF-1 regulates these various proteins in four cell lines. We report that $\mathrm{Mcl}-1$ was the only one of the $10 \mathrm{Bcl}-$ 2 -family proteins regulated by IL- 6 and IFN- $\alpha$. None of these 10 proteins was regulated by IGF-1.

\section{Results \\ Comparative analysis of the survival activity of IL-6, IFN- $\alpha$ and IGF-1 on myeloma cells}

We used myeloma cell lines whose survival and proliferation are dependent on addition of IL-6. In previous studies, we have shown that IFN- $\alpha^{9}$ and IGF- $1^{13}$ are also survival factors for these cell lines. We used serum free culture conditions to avoid the confounding effects of IGF-1 and IGF-binding proteins present in serum and to compare the myeloma cell survival activity of IL-6, IFN- $\alpha$ and IGF-1. Detailed results of one representative experiment with the $\mathrm{XG}-13 \mathrm{HMCL}$ are outlined in Figure 1 and the mean results of 3-6 experiments obtained with four HMCL are displayed in Table 1. When myeloma cells of the four cell lines were IL- 6 and FCS starved, a high percentage of cells bound annexin $V$ (Table 1). On the other hand, annexin $\mathrm{V}^{+}$cells had a DNA profile of apoptotic cells. It should be noted that during the first $24 \mathrm{~h}$ of culture in serum free conditions, more than $85 \%$ of the cells failed to incorporate trypan blue, whereas a high percentage of cells was stained with annexin $\mathrm{V}$. We have confirmed that these annexin $\mathrm{V}^{+}$myeloma cells were apoptotic cells, in agreement with previous findings. ${ }^{29}$ Indeed, when annexin $\mathrm{V}^{+}$and annexin $\mathrm{V}^{-}$cells were sorted and labeled with propidium iodide, annexin $\mathrm{V}^{-}$cells had a PI fluorescence profile of viable cells with a double peak characteristic of cells in the G1 phase and of cells in the G2 and M phases (Figure 2).

Thus, using annexin $\mathrm{V}$ staining, we found that $69 \%$ of the XG-13 cells were apoptotic after 1 day of culture without FCS and exogenous cytokines in the experiment outlined in Figure 1. Adding IL-6 partially but significantly $(P=0.011)$ protected from apoptosis (Table 1$)$. IFN- $\alpha$ and IGF-1 was as potent as IL-6 to reduce apoptosis (Figure 1 and Table $1, P=0.009$ and $P=0.001$ respectively). Similar results were obtained with three other myeloma cell lines: XG-1, XG-2 and XG-6 (Table 1). In previous papers we showed that the cytokine concentrations used here were optimal for inducing the survival of these myeloma cell lines and that no significant further protection was found when either IL- 6 and IFN- $\alpha^{9}$ or IL- 6 and IGF-1 were added. ${ }^{13}$

\section{Expression of $\mathrm{Bcl}-2$-family proteins in myeloma cells}

In order to identify the anti-apoptotic and pro-apoptotic proteins potentially involved in the control of apoptosis, we investigated the expression of Bcl-2-family members in a panel of $11 \mathrm{IL}-6$ dependent myeloma cell lines harvested during the exponential growth phase. Figure $3 \mathrm{~A}$ illustrates the results from Western blot analyses of anti-apoptotic proteins. For each cell line, the same amount of proteins were loaded per lane. All cell lines expressed a similar level of $\mathrm{Mcl}-1$. Bcl-2 and Bcl-xL were variably expressed. $\mathrm{Bcl}-2$ was weakly expressed in four out of the 11 cell lines (XG-1, XG-3, XG-7 and XG-14) and highly expressed in XG-5. Bcl-xL was weakly expressed in two cell lines (XG-3 and XG-13). Bag-1 was also detected in all cell lines at a variable level. Bfl-1/A1 was found in XG-12 only. Concerning the pro-apoptotic proteins (Figure 3B), Bax was weakly expressed in XG-1, XG-2, XG-5, XG-13 and XG-14. Bak and Bid were variably expressed by all cell lines excepted for XG-7, which was negative for Bid. Finally, Bcl-xS and Bad could not be detected in the 11 cell lines (results not shown).

\section{Regulation of Bcl-2-family protein expression by IL-6, IFN- $\alpha$ or IGF-1}

We investigated the proteins that were regulated by IL-6, IFN$\alpha$ or IGF-1. Cells were IL-6 and FCS starved for $1 \mathrm{~h}$ and stimulated by IL- 6 , IFN- $\alpha$, IGF- 1 or no cytokine for several hours. Detailed results for XG-6 are shown in Figure 4. IL-6 and FCS starvation for $2-24 \mathrm{~h}$ resulted in a progressive disappearance of $\mathrm{Mcl}-1$ whereas the levels of $\mathrm{Bcl}-\mathrm{xL}$ and $\mathrm{Bcl}-$ 2 were not reproducibly affected in three separate experiments. This $\mathrm{Mcl}-1$ disappearance was associated at 6 and $24 \mathrm{~h}$ with an increased percentage of annexin $\mathrm{V}$ positive cells, whereas the myeloma cell count remained constant and the percentage of viable cells as assayed by trypan blue 
$\mathrm{OH}$

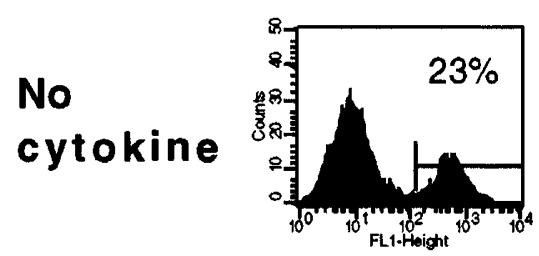

IL - 6

IF $N-\alpha$

IGF-1
$2 \mathrm{H}$
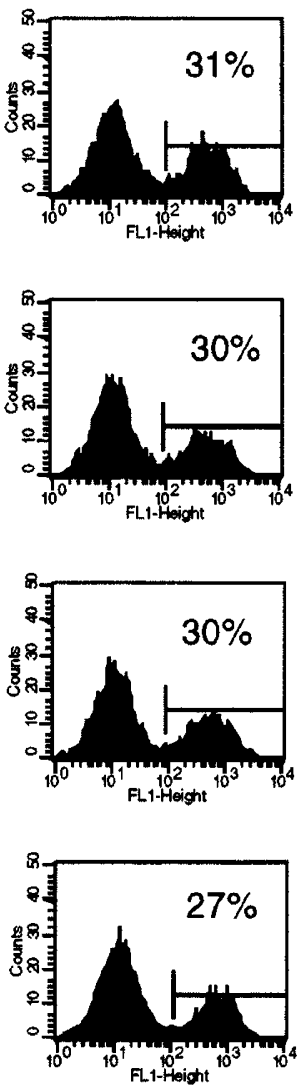

$6 \mathrm{H}$
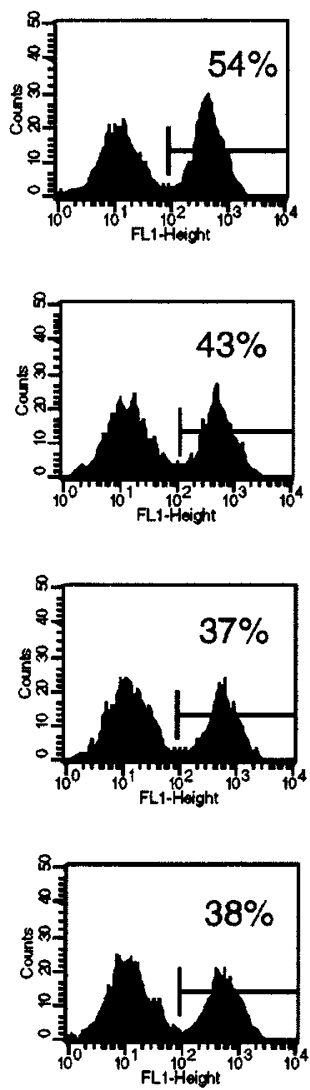

24H
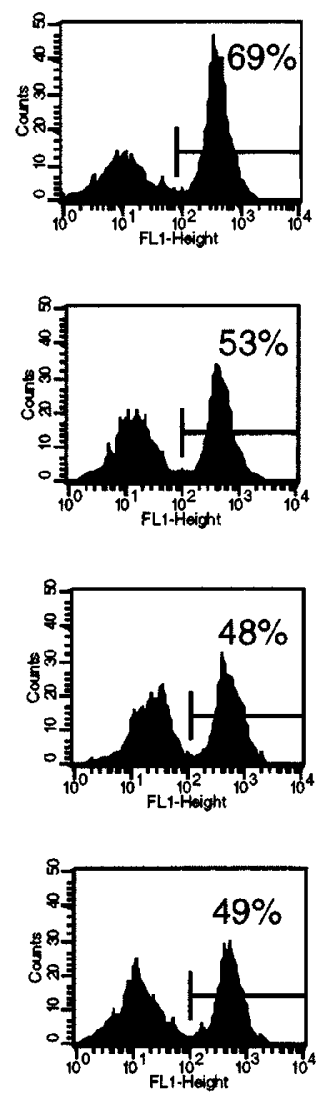

\section{ANNEXIN V}

Figure 1 IL-6, IFN- $\alpha$ and IGF-1 are myeloma cell survival factors. XG-13 cells were harvested during the exponential growth phase with IL-6 and FCS, IL-6 and FCS starved for $1 \mathrm{~h}$ and then cultured for 2,6 or $24 \mathrm{~h}$ with no cytokine, $2 \mathrm{ng} / \mathrm{ml} \mathrm{of} \mathrm{IL-6,200} \mathrm{U/ml} \mathrm{of} \mathrm{IFN-} \alpha$ or $100 \mathrm{ng} / \mathrm{ml}$ of IGF- 1 in RPMI 1640 culture medium and $1 \%$ BSA. At the end of the culture, cells were stained with FITC-annexin V to determine the percentage of apoptotic cells with a FACScan

exclusion remained high (Figure 4). Adding IL-6 reversed $\mathrm{Mcl}-$ 1 disappearance. IL-6 slightly increased $\mathrm{Bcl}-2$ and $\mathrm{Bcl}-\mathrm{xL}$ levels in the experiment outlined in Figure 4. However, this slight increase was not reproduced in other separate experiments. Adding IFN- $\alpha$ also resulted in a dramatic upregulation of $\mathrm{Mcl}-1$ without reproducibility affecting the levels of $\mathrm{Bcl}-\mathrm{xL}$. Bcl-2 was slightly up-regulated by IFN- $\alpha$ in other separate experiments. Finally, we found no IGF-1 upregulation of any of the anti-apoptotic proteins tested (Mcl-1, $\mathrm{Bcl}-\mathrm{xL}, \mathrm{Bcl}-2$ or Bag-1). In these experiments, actin expression was used as a loading control for cells cultured for the first $6 \mathrm{~h}$ since its expression remained stable. However, a decrease in actin expression was detected after $24 \mathrm{~h}$ of culture with no cytokine, which fits its identification as a caspase target. ${ }^{30}$ Accordingly, we used MAPK (ERK1 and ERK2) expression as a loading protein control for experiments shown in Figure 4 because its expression did not vary with the level of apoptosis. Results obtained with XG-6 were further confirmed with three other cell lines (XG-1, XG-2 and XG-13).
As shown in Figure 5, Mcl-1 expression is highly and rapidly regulated in the myeloma cell lines by the two myeloma survival factors, IL- 6 and IFN- $\alpha$, whereas $\mathrm{Bcl}-\mathrm{xL}$ levels were not significantly affected. As for the XG- 6 cells IFN- $\alpha$ slightly increased Bcl-2 in XG-1 cells and IGF-1 did not affect the levels of $\mathrm{Mcl}-1, \mathrm{Bcl}-2$ or Bcl-xL in XG-1 and XG-2 HMCLs. A slight up-regulation of $\mathrm{Mcl}-1$ by IGF-1 was found in XG-13 cells in one experiment (Figure 5); however, this was not reproducible in two other separate experiments.

This lack of $\mathrm{Bcl}-\mathrm{xL}$ regulation by IL- 6 or IFN- $\alpha$ contradicts previous studies suggesting that IL-6 may promote myeloma cell survival by up-regulating $\mathrm{Bcl}-\mathrm{xL}$ expression in the $\mathrm{U}_{266^{25}}$ or the $\mathrm{MDM}^{24}$ myeloma cell lines. In our experiments we used serum-free culture conditions. However, we also found that only $\mathrm{Mcl}-1$ and not $\mathrm{Bcl}-\mathrm{xL}$ was reproducibly increased by IL- 6 when myeloma cells were IL-6 and FCS starved and then cultured with FCS (Figure 6). FCS alone increased $\mathrm{Mcl}-1$ expression (Figure 6 ) in agreement with its myeloma cell survival activity 
Table 1 IL-6, IFN- $\alpha$ and IGF-1 are myeloma cell survival factors

\begin{tabular}{|c|c|c|c|c|c|}
\hline & & & $\operatorname{exin} \mathrm{V}^{+}($ & & \\
\hline & & & Ho & & \\
\hline & & 0 & 2 & 6 & 24 \\
\hline XG-1 & $\begin{array}{c}\text { Co } \\
\text { IL-6 } \\
\text { IFN- } \alpha \\
\text { IGF-1 }\end{array}$ & $34 \pm 10$ & $\begin{array}{l}69 \pm 11 \\
59 \pm 14^{*} \\
59 \pm 14 \\
58 \pm 12\end{array}$ & $\begin{array}{l}74 \pm 8 \\
61 \pm 10 \\
59 \pm 11 \\
60 \pm 11\end{array}$ & $\begin{array}{l}81 \pm 10 \\
61 \pm 14 \\
60 \pm 13 \\
64 \pm 13\end{array}$ \\
\hline & & 0 & 2 & 6 & 24 \\
\hline$X G-2$ & $\begin{array}{l}\text { Co } \\
\text { IL-6 } \\
\text { IFN- } \alpha \\
\text { IGF-1 }\end{array}$ & $25 \pm 6$ & $\begin{array}{l}49 \pm 12 \\
43 \pm 15^{\star} \\
42 \pm 14^{*} \\
44 \pm 17^{\star}\end{array}$ & $\begin{array}{l}67 \pm 17 \\
55 \pm 18 \\
49 \pm 18 \\
59 \pm 16\end{array}$ & $\begin{array}{l}82 \pm 15 \\
58 \pm 18 \\
48 \pm 14 \\
68 \pm 19\end{array}$ \\
\hline & & 0 & 6 & 24 & 48 \\
\hline$X G-6$ & $\begin{array}{l}\text { Co } \\
\text { IL-6 } \\
\text { IFN- } \alpha \\
\text { IGF-1 }\end{array}$ & $14 \pm 1$ & $\begin{array}{l}28 \pm 6 \\
21 \pm 7 \\
19 \pm 7 \\
24 \pm 6\end{array}$ & $\begin{array}{l}52 \pm 27 \\
36 \pm 25 \\
36 \pm 25 \\
46 \pm 28\end{array}$ & $\begin{array}{l}58 \pm 24 \\
36 \pm 23 \\
41 \pm 24 \\
48 \pm 24\end{array}$ \\
\hline & & 0 & 2 & 6 & 24 \\
\hline$X G-13$ & $\begin{array}{l}\text { Co } \\
\text { IL-6 } \\
\text { IFN- } \alpha \\
\text { IGF-1 }\end{array}$ & $28 \pm 5$ & $\begin{array}{l}39 \pm 7 \\
36 \pm 5^{*} \\
34 \pm 5^{*} \\
32 \pm 5\end{array}$ & $\begin{array}{l}51 \pm 3 \\
39 \pm 7 \\
35 \pm 6 \\
35 \pm 6\end{array}$ & $\begin{array}{l}62 \pm 14 \\
45 \pm 17 \\
44 \pm 14 \\
42 \pm 14\end{array}$ \\
\hline
\end{tabular}

Myeloma cells were harvested during the exponential growth phase with IL- 6 and FCS, IL- 6 and FCS starved for $1 \mathrm{~h}$ and then cultured for 2,6 , 24 or $48 \mathrm{~h}$ with no jcytokine, $2 \mathrm{ng} / \mathrm{ml}$ of IL-6, $200 \mathrm{U} / \mathrm{ml}$ of IFN- $\alpha$ or $100 \mathrm{ng} / \mathrm{ml}$ of IGF-1 in RPMl 1640 culture medium and $1 \%$ BSA. At the end of the culture, cells were stained with FITCannexin $\mathrm{V}$ to determine the percentage of apoptotic cells and analyzed with a FACScan. Results are mean values \pm S.D. of $3-6$ different experiments. In all these experiments, the percentage of viable cells assayed by trypan blue exclusion was not significantly affected during the first $24 \mathrm{~h}$ of culture. Except when indicated $\left(^{*}\right)$, the mean percentage of apoptotic cells in the culture group with cytokines is significantly different $(P<0.05)$ from corresponding control groups $($ Control at 2 or $48 \mathrm{~h})$, as determined by a Student $t$-test for pairs

(unpublished observations). As Bcl-xL is known to have a longer half-life than Mcl-1, XG-6 myeloma cells were IL-6 starved for $24 \mathrm{~h}$ in presence of FCS and cultured with or without IL-6 for $96 \mathrm{~h}$. As shown in Figure 7, IL-6 starvation induced apoptosis in myeloma cells and accordingly to our previous results in serum-free culture conditions, we found a strong decrease in $\mathrm{Mcl}-1$ expression following IL-6 withdrawal that was abolished by adding IL-6. On the contrary, we found no decrease or increase of $\mathrm{Bcl}-\mathrm{xL}$ levels. Same results were obtained with the XG-1 and XG-2 myeloma cell lines in long-term culture conditions $(96 \mathrm{~h}$, results not shown). Finally, to confirm the lack of $\mathrm{BCl}-\mathrm{xL}$ regulation by either IL- 6 or IFN- $\alpha$, we used a second different anti-Bcl-xL antibody that yielded similar results (results not shown). In addition, we checked that these two antibodies specifically recognized recombinant $\mathrm{Bcl}-\mathrm{xL}$ (results not shown).

For the pro-apoptotic proteins, we found no regulation or induction of Bax, Bak (Figure 4), Bid, Bcl-xS and Bad expression (results not shown).

\section{Differential activation of Stat3 by IL-6, IFN- $\alpha$ and IGF-1}

We previously reported that IL-6 and IFN- $\alpha$, unlike IGF-1, activated Stat3 in XG-1 and XG-2 cell lines. ${ }^{9,13}$ We confirmed in the present study that Stat3 was rapidly phosphorylated after activation by IL- 6 and IFN- $\alpha$ in two other cell lines, XG- 6 and XG-13 (Figure 8). Stat3 phosphorylation lasted for more than $6 \mathrm{~h}$. As expected, IGF-1 did not induce Stat3 phosphorylation in these two cell lines (Figure 8). However, IL-6, IFN- $\alpha$ and IGF-1 induced ERK1 and ERK2 phosphorylation.

\section{Discussion}

As the survival regulation of tumor cells is a key process in multiple myeloma biology, the aim of the current study was to identify the anti-apoptotic and pro-apoptotic proteins of Bcl-2family proteins that were regulated in myeloma cells by three survival factors: IL-6, IFN- $\alpha$ and IGF-1. We used myeloma cell lines whose survival and proliferation are dependent on addition of exogenous growth factors. ${ }^{28}$

We used serum-free culture conditions to avoid the interference of serum proteins with these growth factors, in particular the IGF binding proteins. In addition, FCS contains unidentified survival factors that might mask the effect of recombinant cytokines. In serum-free culture conditions, the level of apoptosis was more or less marked depending on the cell lines and on various parameters such as initial cell count and viability. Apoptotis was measured by the binding of annexin $\mathrm{V}$ due to the exposure of phosphatidylcholine outside the cell. Sorting the annexin $\mathrm{V}^{+}$ and annexin $\mathrm{V}^{-}$cells and staining DNA with propidium iodide, the annexin $\mathrm{V}^{-}$cells were proved to have the DNA profile of viable cells, unlike annexin $\mathrm{V}^{+}$cells. We also 


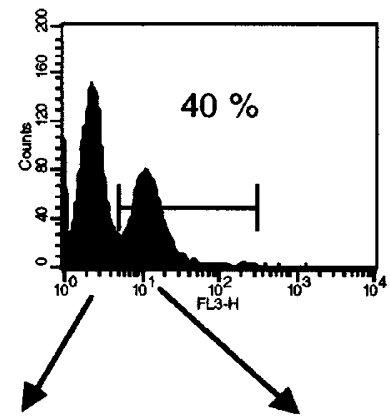

Annexin V-
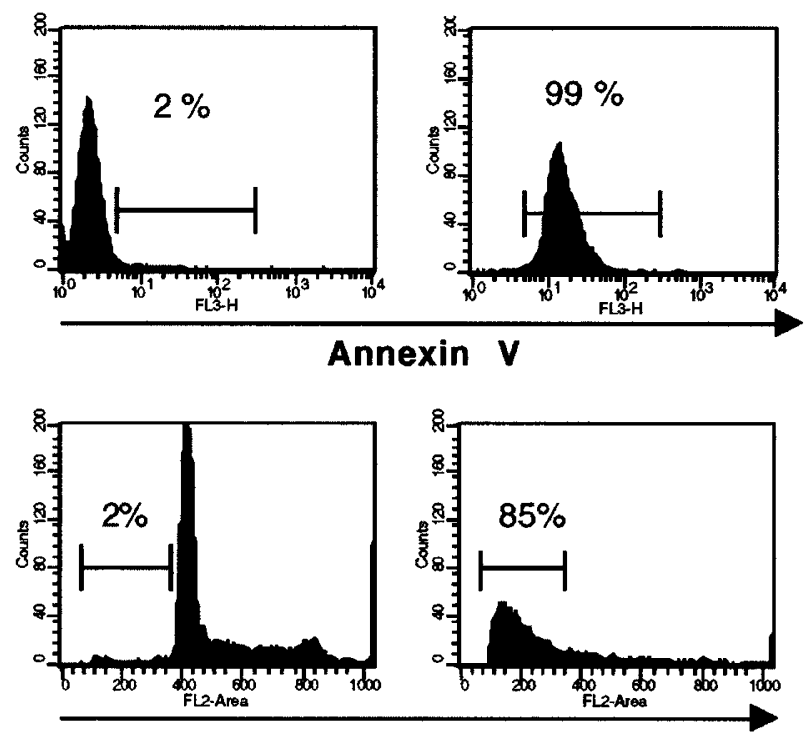

DNA

Figure 2 Sorting and propidium iodide staining of annexin $\mathrm{V}^{-}$and annexin $\mathrm{V}^{+}$myeloma cell lines. XG-6 cells were IL-6 starved for $24 \mathrm{~h}$ and stained with FITC-annexin V. In the experiment outlined in the Figure, $40 \%$ of XG- 6 cells were annexin $\mathrm{V}^{+}$. Annexin $\mathrm{V}^{+}$and annexin $\mathrm{V}^{-}$cells were sorted using a FACS-Vantage cell sorter and DNA was labeled with PI. Results are the FACS profiles of annexin $V$ staining of the unsorted and sorted populations as well as the profiles of DNA staining by PI. The percentages of annexin $\mathrm{V}^{+}$cells or of cells with DNA content less than $\mathrm{G} 1$ are indicated in the panels

found apoptosis induction in myeloma cells after IL-6 starvation by internucleosomal cleavage of DNA (results not shown). For all the cell lines, adding IL-6, IFN- $\alpha$ or IGF1 significantly reduced the apoptosis and the effect was even more pronounced after $24 \mathrm{~h}$ of culture. The three cytokines yielded a significant level of survival and had no additive survival effects when combined.

We investigated 10 proteins of the $\mathrm{Bcl}-2$ family that were expressed in a panel of 11 myeloma cells during exponential growth. Bcl-2, Bcl-xL and $\mathrm{Mcl}-1$ anti-apoptotic proteins were detected in all cell lines. Their expressions varied according to the different cell lines, except for Mcl-1, and did not statistically correlate with each other. Bag-1 was also detected in all cell lines. Bf1-1/A1 expression in only one out of 11 cell lines is noteworthy because earlier studies have shown the association of $\mathrm{Bfl}-1 / \mathrm{A} 1$ expression with the survival of murine plasma cells. ${ }^{31} \mathrm{We}$ also looked for the expression of anti-apoptotic proteins. Bak and Bax were variably expressed in all cell lines, the latter weakly expressed in five cell lines. We detected Bid in 10 out of 11 cell lines. Bad was not detected, which may be attributed to its usual very low expression in myeloma cells. ${ }^{27}$

As the susceptibility to apoptosis is determined in part by the relative concentrations of pro- and anti-apoptotic Bcl-2-family members, we studied their fluctuation in four myeloma cell lines induced into apoptosis after withdrawal of survival factors. We also studied their fluctuation when cells were rescued from apoptosis by adding three different survival factors: IL-6, IFN- $\alpha$ or IGF-1. In the four cell lines, Mcl-1 was the only anti-apoptotic protein whose expression dramatically decreased when cells were IL-6 starved. Removal of cytokines did not reproducibly affect the expression of other anti-apoptotic proteins $(\mathrm{Bcl}-\mathrm{xL}, \mathrm{Bcl}-$ 2, Bag-1); nor did this affect the expression of the proapoptotic proteins Bax, Bak or Bid. Bad remained undetectable when cells underwent apoptosis. Adding IL6 or IFN- $\alpha$ up-regulated $\mathrm{Mcl}-1$ expression without affecting the expression of other anti-apoptotic or pro-apoptotic members. Interestingly, adding IGF-1, as potent a survival factor as IL- 6 or IFN- $\alpha$, did not induce Mcl- 1 expression nor affect the other Bcl-2 members. Using four cell lines whose survival depends strictly on adding exogenous cytokines, we failed to confirm previous results obtained with the MDN IL-6-dependent myeloma cell line, showing that $\mathrm{BCl}-\mathrm{xL}$ was up-regulated by adding IL-6. ${ }^{24}$ In the U266 cell line, a blockage of Stat3 by a dominant-negative Stat3 induces apoptosis in association with a decrease in $\mathrm{Bcl}-\mathrm{xL}$ expression. $^{25}$ To rule out a technical artefact, this lack of $\mathrm{Bcl}-\mathrm{xL}$ regulation was confirmed with a second anti-Bcl-xL antibody. We checked the specificity of these antibodies by immunoblot using the recombinant $\mathrm{Bcl}-\mathrm{xL}$ protein. Another possibility to explain the lack of $\mathrm{Bcl}-\mathrm{xL}$ regulation is that, contrary to Puthier et al., ${ }^{24}$ we used serum-free culture conditions to comparatively study the effects of IL6 , IFN- $\alpha$ and IGF-1. Indeed $\mathrm{Bcl}-\mathrm{xL}$ has a longer half-life compared to $\mathrm{Mcl}-1$ and the duration of IL-6 withdrawal can be too short to get a Bcl-xL down-regulation. However, we also found no $\mathrm{Bcl}-\mathrm{xL}$ down-regulation when myeloma cells were starved of IL-6 and cultured with FCS for $96 \mathrm{~h}$ whereas a great fraction of myeloma cells apoptosed. Addition of IL-6 did not result in Bcl-xL up-regulation. In agreement with our findings in serum-free conditions, we found that $\mathrm{Mcl}-1$ was decreased after II- 6 withdrawal and increased after IL- 6 addition in these long-term culture experiments. Thus, a change in the $\mathrm{Bcl}-\mathrm{xL}$ level when myeloma cells are induced to survive with IL-6 is not a common characteristic and may be restricted to particular cell lines. On the other hand, the Mcl-1 level appears to be strongly regulated by IL- 6 but also by IFN- $\alpha$ in all the cell lines we have studied so far. Previous studies have shown that Mcl-1 expression was correlated with the survival of normal B lymphocytes ${ }^{32}$ or neutrophils. ${ }^{33}$ Transfection of Mcl-1 cDNA in hematopoietic cells makes it possible to promote their survival in culture conditions favoring apoptosis. ${ }^{34}$ Increased survival of hematopoietic and lymphoid cells was found in $\mathrm{Mcl}-1$ transgenic mice. In addition, myeloid cell lines were obtained from these $\mathrm{Mcl}-1$ transgenic mice. ${ }^{35}$ 
A

\section{ANTI-APOPTOTIC PROTEINS}

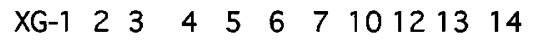

\section{$\mathrm{BCl}-2$}

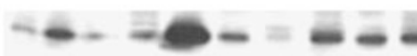

$\mathrm{Bcl}-\mathrm{xL}$

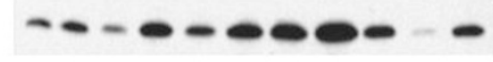

$\mathrm{Mcl}-1$

$-\infty------0$

Bag-1

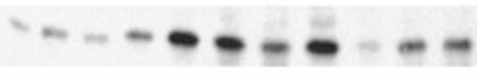

Bfl-1

$\mathrm{B}$ actin - - - - - - -
B

\section{PRO-APOPTOTIC PROTEINS}

$\begin{array}{lllllllllll}X G-1 & 2 & 3 & 4 & 5 & 6 & 7 & 10 & 12 & 13 & 14\end{array}$

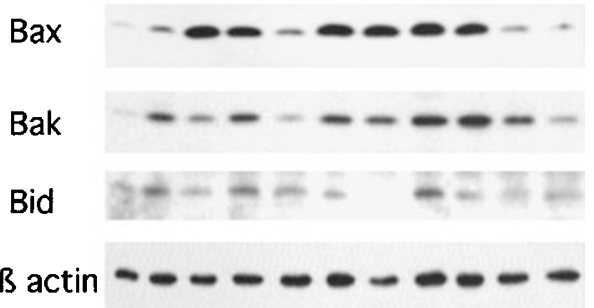

Figure 3 Immunoblot analysis of Bcl-2-family protein expression on myeloma cells. Cell lysates were obtained from myeloma cells harvested during the exponential growth phase with IL- 6 and FCS. An equal amount of protein ( $25 \mu \mathrm{g}$ per lane) was loaded for each HMCL and $\beta$ actin expression is shown as a control. Expression of anti-apoptotic proteins $(\mathbf{A})$ and of pro-apoptotic proteins (B)

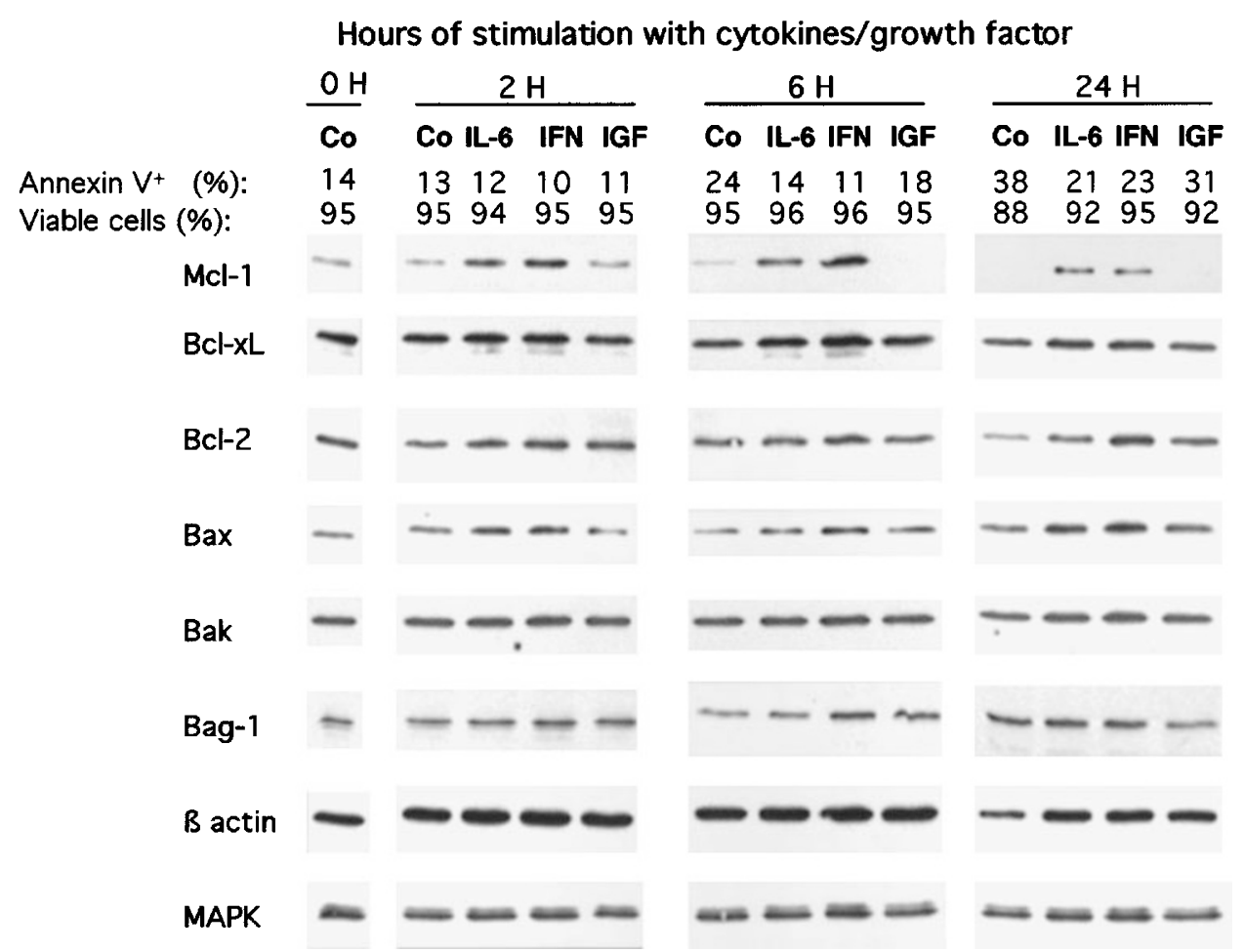

Figure 4 Regulation of Bcl-2-family protein expression by IL-6, IFN- $\alpha$ or IGF- 1 on XG- 6 myeloma cells. XG- 6 myeloma cells were IL-6 and FCS starved for $1 \mathrm{~h}$ and cultured for 2, 6 and $24 \mathrm{~h}$ with no cytokine (Co), $2 \mathrm{ng} / \mathrm{ml} \mathrm{IL-6}$ (IL-6), $200 \mathrm{U} / \mathrm{ml} \mathrm{IFN-} \alpha$ (IFN- $\alpha$ ) or $100 \mathrm{ng} / \mathrm{ml}$ IGF-1 (IGF) in RPMI1640 and $1 \%$ BSA. At the end of the culture, the cell count and the percentage of viable cells were assayed by trypan blue exclusion. The percentages of apoptotic cells were determined by staining with FITC-annexin V. Cells were immediately lysated and assayed for Bcl-2-family protein expression using Western blot analysis. The amount of proteins was carefully determined and $25 \mu \mathrm{g}$ of total proteins from each culture group were loaded on the gel. In the experiments, MAPK expression was used as loading protein control because it was not affected by the level of apoptosis. Western blots are for one representative experiment out of three

A common transduction pathway induced in myeloma cell lines by IL- 6 and IFN- $\alpha$ is the activation of JAK kinases and tyrosine phosphorylation of STAT factors, mainly Stat3. ${ }^{36,37}$ We have extended our previous observations ${ }^{9}$ and show that IL- 6 and IFN- $\alpha$ induced Stat3 phosphorylation in the four cytokine-dependent cell lines studied here. Stat1 was inconsistently found phosphorylated in myeloma cell lines after IL-6 or IFN- $\alpha$ activation, in agreement with 


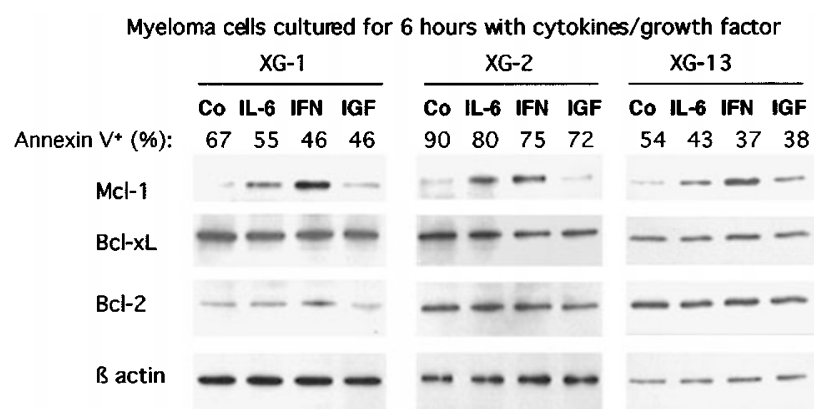

Figure 5 Regulation of $\mathrm{Bcl}-2$-family protein expression by cytokines or growth factors in myeloma cell lines. XG-1, XG-2 and XG-13 myeloma cells were processed as indicated in the legend of Figure 4. Results are expression of $\mathrm{Bcl}-2$-family proteins using Western blot analysis after $6 \mathrm{~h}$ of culture with no cytokine (Co), $2 \mathrm{ng} / \mathrm{ml} \mathrm{IL-6} \mathrm{(IL-6),} 200 \mathrm{U} / \mathrm{ml} \mathrm{IFN- \alpha}$ (IFN- $\alpha$ ) or $100 \mathrm{ng} / \mathrm{ml} \mathrm{IGF-1}$ (IGF) in RPMI1640 and 1\% BSA. Western blots are for one representative experiment out of $2-4$, depending on the cell line

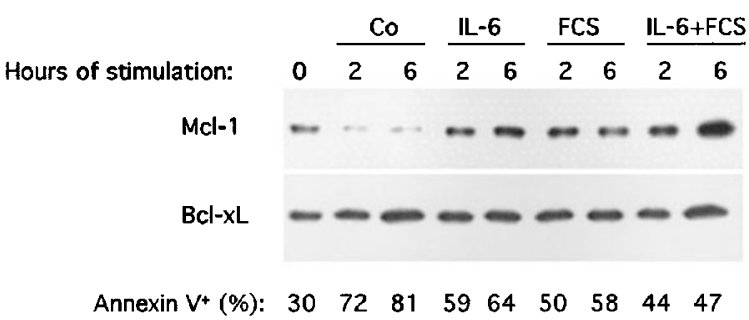

Figure $6 \mathrm{Mcl}-1$ and not $\mathrm{Bcl}-\mathrm{xL}$ regulation by IL-6 in FCS culture conditions. XG-1 myeloma cells were processed as indicated in the legend of Figure 4 Results are $\mathrm{Mcl}-1$ and $\mathrm{Bcl}-\mathrm{xL}$ protein expression using Western blot analysis after 2 or $6 \mathrm{~h}$ of culture with no cytokine (Co), $2 \mathrm{ng} / \mathrm{ml} \mathrm{IL-6} \mathrm{(IL-6),} 10 \%$ FCS or $2 \mathrm{ng} / \mathrm{ml} \mathrm{IL-6}$ and $10 \%$ FCS (IL-6+FCS). Western blots are for one representative experiment out of three

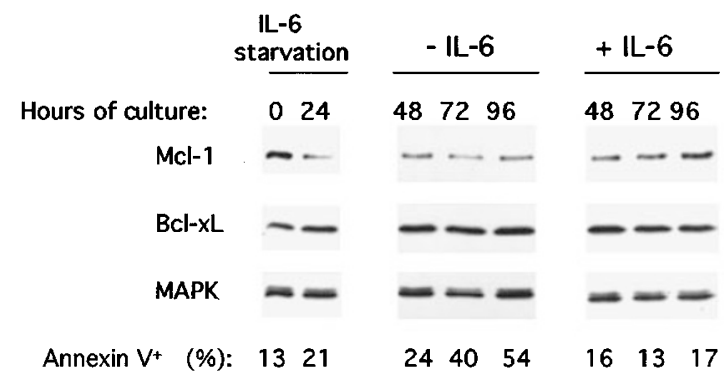

Figure 7 Lack of $\mathrm{Bcl}-\mathrm{xL}$ regulation by IL- 6 in long-term culture conditions. XG- 6 cells were IL- 6 starved for $24 \mathrm{~h}$ in RPMI 1640 with $10 \%$ FCS and cultured with or without IL-6 in presence of FCS for $24,48,72$ or $96 \mathrm{~h}$. At the end of the culture the cells were processed as indicated in the legend of Figure 4

previous observations. ${ }^{9,38}$ It was recently shown that blocking JAK activity and/or Stat3 activation by tyrphostin AG490 or a Stat3 mutant induced U266 cells to apoptosis in association with a down-regulation of $\mathrm{BCl}-\mathrm{xL} .{ }^{25}$ In the MDM myeloma cell line, blocking JAK activation by tyrphostin AG490 also blocked Mcl-1 induction by IL-6. ${ }^{39}$ We have recently shown that inhibiting JAK2 and JAK1 activation by tyrphostin AG490 induced a strong apoptosis in the IL-6-dependent myeloma cell lines used in the

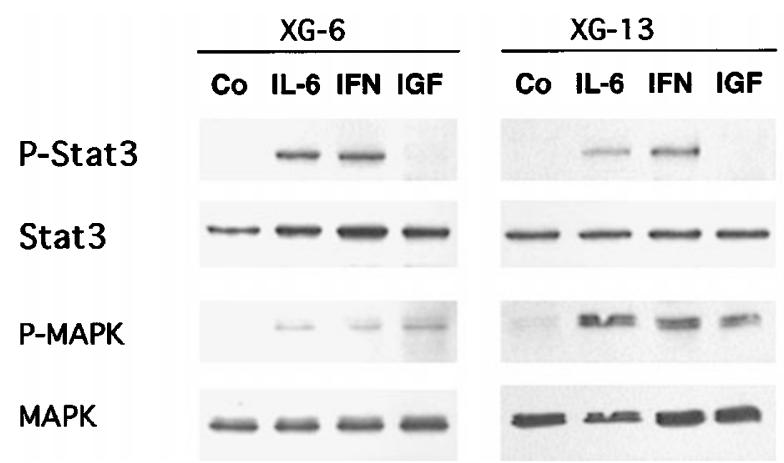

Figure 8 Stat3, ERK1 and ERK2 phosphorylation in myeloma cells stimulated with IL-6, IFN- $\alpha$ or IGF-1. Myeloma cells were IL-6 and FCS starved for $1 \mathrm{~h}$ and cultured with no cytokine (Co), $2 \mathrm{ng} / \mathrm{ml} \mathrm{IL-6} \mathrm{(IL-6),} 200 \mathrm{U} / \mathrm{ml}$ IFN- $\alpha$ (IFN- $\alpha$ ) or $100 \mathrm{ng} / \mathrm{ml}$ IGF-1 (IGF) in RPMI1640 and $1 \%$ BSA. Stat3 phosphorylation was analyzed by Western blot after $6 \mathrm{~h}$ of culture using phospho-specific Stat3 antibody (P-Stat3), ERK1 and ERK2 phosphorylation after $15 \mathrm{~min}$ of culture using phospho-specific MAPK (P-MAPK). Blots were then stripped and reprobed for Stat3 or total MAPK. Western blots are for one representative experiment out of three

current study, in association with a blockage of Stat3 activation and ERK2 activation. ${ }^{40}$ These studies argue that the myeloma cell survival activity of IL-6 or IFN- $\alpha$ is linked to JAK/Stat pathway activation, yielding an up-regulation of $\mathrm{Mcl}-1$ or $\mathrm{Bcl}-\mathrm{xL}$ expression depending on the myeloma cell line.

The myeloma cell survival activity of IGF-1 is not associated with an up-regulation of $\mathrm{Mcl}-1$ or of other antiapoptotic proteins, a finding consistent with its lack of JAK/ Stat pathway activation. These results are in agreement with our previous findings, showing that the myeloma cell survival factor activity of IGF-1 is not linked to gp130 IL-6 transducer activation through stimulation of an autocrine gp130 cytokine. ${ }^{13}$ IGF-1 is known to activate the Ras/MAP kinase and $\mathrm{Pl}-3$ kinase pathway in several cell lines; however, in preliminary experiments we failed to inhibit its survival activity by adding wortmannin, a PI-3 kinase inhibitor or PD098059, a MAPK kinase inhibitor (results not shown). Apoptosis is not regulated only by the relative levels of the anti-apoptotic and pro-apoptotic proteins but also by their phosphorylation or activation of other apoptosis effectors. In addition, all the members of the $\mathrm{Bcl}-2$ family have not been studied here due to the lack of commercially available reagents. As IGF-1 is present in high amounts in the bone marrow, the tissue in which myeloma cells develop, the understanding of the mechanisms involved in the survival activity of IGF-1 requires further study.

\section{Materials and Methods}

\section{Cytokines and antibodies}

Purified human recombinant IL-6 was kindly provided by Sandoz Forschunginstitut (Vienna, Austria) and human recombinant IFN- $\alpha-2 b$ by Schering Plough (Dardilly, France). Recombinant purified IGF-1 was purchased from R\&D (Minneapolis, MN, USA), monoclonal anti- 
Bcl-2 antibody from Dako (Copenhagen, Denmark), anti- $\beta$ actin from Sigma (St Louis, MO, USA) and anti-Stat3 from Transduction Laboratories (Lexington, KY, USA). Rabbit or goat polyclonal antibodies specific for Bcl-x, Mcl-1, Bag-1, Bak, Bfl-1/A1, Bid and ERK2 were obtained from Santa Cruz Biotechnology (Santa Cruz, CA, USA), Bad, phospho-Stat3 and phospho-ERK1 and ERK2 from New England Biolabs (Beverly, MA, USA), Bax from Upstate Biotechnology (Lake Placid, NY, USA) and a second anti-Bcl-x from Transduction Laboratories. Recombinant human Bcl-xL was obtained from Santa Cruz Biotechnology.

\section{Human myeloma cell lines (HMCL)}

XG-1, XG-2, XG-3, XG-4, XG-5, XG-6, XG-7, XG-10, XG-12, XG-13 and $X G-14$ myeloma cell lines were obtained from 11 patients with terminal disease. The HMCL were established as described previously. ${ }^{28}$ These HMCLs are true myeloma cell lines: CD19$\mathrm{CD}^{-}{ }^{-}, \mathrm{CD}_{138^{+}}, \mathrm{CD}_{38^{2+}}$, cytoplasmic immunoglobulin ${ }^{2+}$. They are not infected with EBV. ${ }^{28}$ Their growth is dependent upon addition of exogenous IL-6, as does the growth of primary cells. Cells were free of mycoplasma contamination as assayed using the Boehringer Mannheim kit of detection (Mannheim, Germany).

\section{Culture of myeloma cells}

The HMCLs were routinely cultured with $2 \mathrm{ng} / \mathrm{ml}$ of IL-6 in RPMI 1640 supplemented with $10 \%$ fetal calf serum (FCS) and $5 \times 10^{-5} \mathrm{M} 2$ mercaptoethanol. In order to comparatively investigate the mechanisms involved in the myeloma cell survival activity of IL-6, IFN- $\alpha$ or IGF1 , we used serum-free culture conditions to avoid the confounding effects of IGF-1 and IGF binding proteins present in serum. Therefore, the HMCLs were washed twice, cultured for $1 \mathrm{~h}$ in RPMI1640 supplemented with $1 \%$ bovine serum albumin (BSA, Sigma) and washed once again. Cells were then cultured at a concentration of $2 \times 10^{5}$ cells $/ \mathrm{ml}$ in RPMI $1640,1 \%$ BSA with either no cytokine, IL-6 (2 $\mathrm{ng} / \mathrm{ml}), \mathrm{IFN}-\alpha(200 \mathrm{U} / \mathrm{ml})$ or IGF-1 $(100 \mathrm{ng} / \mathrm{ml})$ for 2,6 and $24 \mathrm{~h}$. In other experiments, myeloma cells were starved of IL- 6 for $24 \mathrm{~h}$ in presence of FCS (RPMl1640+10\% FCS), washed twice and cells were cultured with FCS with or without IL-6 $(2 \mathrm{ng} / \mathrm{ml})$ for $24,48,72$ or $96 \mathrm{~h}$ at a concentration of $2 \times 10^{5}$ cells $/ \mathrm{ml}$.

\section{Assays for detection of apoptotic cells}

Apoptotic cells were detected by using fluorescein isothiocyanatelabeled annexin V (FITC-annexin-V, Boehringer Mannheim). Annexin V has a high affinity for phosphatidylserine present on the outer cytoplasmic membrane of apoptotic cells. ${ }^{29}$ Cells were washed, labeled with FITC-annexin-V according to the manufacturer's recommendations and analyzed with a FACScan flow cytometer using Cell Quest software (Becton Dickinson, Mountain View, CA, USA). In one experiment, annexin $\mathrm{V}^{+}$and annexin $\mathrm{V}^{-}$cells were sorted using a Vantage cell sorter (Becton Dickinson) and the cell cycle was analyzed by propidium iodide-DNA staining as previously described. ${ }^{41}$

\section{Western blot analysis}

Cells were lysated in $10 \mathrm{mM}$ Tris- $\mathrm{HCl}(\mathrm{pH} 7.05), 50 \mathrm{mM} \mathrm{NaCl}, 50 \mathrm{mM}$ $\mathrm{NaF}, 30 \mathrm{mM}$ sodium pyrophosphate (NaPPi), 1\% Triton $\mathrm{X}-100,5 \mu \mathrm{M}$
$\mathrm{ZnCl}_{2}, 100 \mu \mathrm{M} \mathrm{Na} \mathrm{VO}_{4}, 1 \mathrm{mM}$ DTT, $20 \mathrm{mM}$ b-glycerophosphate, $20 \mathrm{mM}$ p-nitrophenolphosphate (PNPP), $2.5 \mu \mathrm{g} / \mathrm{ml}$ aprotinin, $2.5 \mu \mathrm{g} / \mathrm{ml}$ leupeptin, $0.5 \mathrm{mM}$ PMSF, $0.5 \mathrm{mM}$ benzamidine, $5 \mu \mathrm{g} / \mathrm{ml}$ pepstatin and $50 \mathrm{nM}$ okadaik acid. The protein content of each lysate was quantified using the bicinchoninic acid kit (Sigma). Aliquots containing $50 \mu \mathrm{g}$ of total protein were resolved in $12 \%$ sodium dodecyl sulfatepolyacrylamide by gel electrophoresis (SDS-PAGE) and transferred to a nitrocellulose membrane (Schleicher and Schuel, Dassel, Germany). Membranes were blocked for $2 \mathrm{~h}$ at room temperature in $140 \mathrm{mM} \mathrm{NaCl}, 3 \mathrm{mM} \mathrm{KCl}, 25 \mathrm{mM}$ Tris- $\mathrm{HCl}(\mathrm{pH} 7.4), 0.1 \%$ tween 20 (TBS-T), $5 \%$ non-fat milk), then incubated for $1 \mathrm{~h}$ at room temperature with primary antibodies. The primary antibodies were visualized with goat anti-rabbit (Sigma) or goat anti-mouse (Biorad SA, Yvry Sur Seine, France) peroxydase-conjugated antibodies (at 1:10 000 dilution in TBS-T) using an enhanced chemiluminescence detection system. The membranes were stripped twice with $100 \mathrm{mM}$ Glycin, $\mathrm{pH} 2.2,0.1 \% \mathrm{NP} 40$ and $1 \%$ SDS for $30 \mathrm{~min}$ at room temperature. Blots were quantified by densitometry using acquisition into Adobe Photo Shop (Apple, Cupertino, CA, USA) and analyzing by the $\mathrm{NIH}$ Image softwares (National Institutes of Health, Bethesda, MD, USA). In the case of the experiments performed with exponentially growing cell lines, the level of protein expression was normalized according to $\beta$ actin expression.

\section{Statistical analysis}

The mean percentages of apoptotic cells in the culture groups with cytokines were compared to corresponding control groups and the statistical significance was evaluated by using the Student $t$-test for pairs. To look for a correlation of Bcl-2-family protein expression among the various myeloma cell lines, the non-parametric Spearman correlation test was used.

\section{Acknowledgments}

This work was supported by a grant from the Ligue Contre le Cancer (Paris, France).

\section{References}

1. Greipp PR, Katzmann JA, O'Fallon WM and Kyle RA (1988) Value of beta 2microglobulin level and plasma cell labeling indices as prognostic factors in patients with newly diagnosed myeloma. Blood 72: 219-223

2. Drewinko B and Alexanian R (1977) Growth kinetics of plasma cell myeloma. J. Nat. Cancer Inst. 58: 1247

3. Slifka MK, Antia R, Whitmire JK and Ahmed R (1998) Humoral immunity due to long-lived plasma cells. Immunity 8: 363-372

4. Merville P, Dechanet J, Desmouliere A, Durand I, Debouteiller O, Garrone P Banchereau J and Liu YJ (1996) Bcl-2(+) tonsillar plasma cells are rescued from apoptosis by bone marrow fibroblasts. J. Exp. Med. 183: 227-236

5. Gu ZJ, Vos JD, Rebouissou C, Jourdan M, Zhang XG, Rossi JF, Wijdenes J and Klein B (2000) Agonist anti-gp130 transducer monoclonal antibodies are human myeloma cell survival and growth factors. Leukemia 14: 188-197

6. Zhang XG, Gu ZJ, Lu ZY, Yasukawa K, Yancopoulos GD, Turner K, Shoyab M, Taga T, Kishimoto T, Bataille R and Klein B (1994) Ciliary neurotropic factor, interleukin 11, leukemia inhibitory factor, and oncostatin $M$ are growth factors for human myeloma cell lines using the interleukin 6 signal transducergp130. J. Exp. Med. 179: 1337-1342 
7. Nishimoto N, Ogata A, Shima $Y$, Tani $Y$, Ogawa H, Nakagawa M, Sugiyama $H$, Yoshizaki Kand Kishimoto T (1994) Oncostatin M, leukemia inhibitory factor, and interleukin- 6 induce the proliferation of human plasmacytoma cells via the common signal transducer, gp130. J. Exp. Med. 179: 1343-1347

8. Westendorf JJ and Jelinek DF (1996) Growth regulatory pathways in myeloma. Evidence of autocrine oncostatin M expression. J. Immunol. 157: 3081-3088

9. Ferlin-Bezombes M, Jourdan M, Liautard J, Brochier J, Rossi JF and Klein B (1998) IFN-alpha is a survival factor for human myeloma cells and reduces dexamethasone-induced apoptosis. J. Immunol. 161: 2692-2699

10. Liu P, Oken M and Van Ness B (1999) Interferon-alpha protects myeloma cel lines from dexamethasone-induced apoptosis. Leukemia 13: 473-480

11. Xu F, Gardner A, Tu Y, Michl P, Prager D and Lichtenstein A (1997) Multiple myeloma cells are protected against dexamethasone-induced apoptosis by insulin-like growth factors. Br. J. Haematol. 97: 429-440

12. Georgii-Hemming $P$, Wiklund HJ, Ljunggren $O$ and Nilsson $K$ (1996) Insulin-like growth factor $I$ is a growth and survival factor in human multiple myeloma cell lines. Blood 88: 2250-2258

13. Ferlin M, Noraz N, Hertogh C, Brochier J, Taylor N and Klein B (2000) Insulin-like growth factor induces the survival and proliferation of myeloma cells through an IL-6-independent transduction pathway. Br. J. Haematol. (in press)

14. Gross A, McDonnell JM and Korsmeyer SJ (1999) BCL-2 family members and the mitochondria in apoptosis. Genes Dev. 13: 1899-1911

15. Adams JM and Cory S (1998) The Bcl-2 protein family: arbiters of cell survival. Science 281: $1322-1326$

16. Takayama S, Sato T, Krajewski S, KochelK, Irie S, Millan JA and Reed JC (1995) Cloning and functional analysis of BAG-1: a novel Bcl-2-binding protein with anticell death activity. Cell 80: 279-284

17. Hamilton MS, BarkerHF, Ball J, Drew M, Abbot SD and Franklin IM (1991) Norma and neoplastic human plasma cells express bcl-2 antigen. Leukemia 5:768-771

18. Pettersson M, Jernberg-Wiklund H, Larsson LG, Sundstrom C, GivolI, Tsujimoto Y and Nilsson K (1992) Expression of the bcl-2 gene in human multiple myeloma cell lines and normal plasma cells. Blood 79: 495-502

19. Ong F, Nieuwkoop JAV, Degrootswings GMJS, Hermans J, Harvey MS, Kluin PM and Kluinnelemans JC (1995) Bcl-2 protein expression is not related to short survival in multiple myeloma. Leukemia 9: 1282-1284

20. Harada N, Hata H, Yoshida M, Soniki T, Nagasaki A, Kuribayashi N, Kimura T, Matsuzaki $\mathrm{H}$ and Mitsuya $\mathrm{H}$ (1998) Expression of Bcl-2 family of proteins in fresh myeloma cells. Leukemia 12: 1817-1820

21. PuthierD, Pellat-Deceunynck C, Barille S, RobillardN, Rapp MJ, Juge-Morineau N, Harousseau JL, Bataille R and Amiot M (1999) Differential expression of Bcl-2 in human plasma cell disorders according to proliferation status and malignancy. Leukemia 13: 289-294

22. Lichtenstein A, Tu YP, Fady C, Vescio R and Berenson J (1995) Interleukin-6 inhibits apoptosis of malignant plasma cells. Cell Immunol. 162: 248-255

23. Schwarze MMK and Hawley RG (1995) Prevention of myeloma cell apoptosis by ectopic bcl-2 expression or interleukin 6-mediated up-regulation of bcl-x(L). Cancer Res. 55: 2262-2265

24. Puthier D, Derenne S, Barille S, Moreau P, Harousseau JL, Bataille R and Amiot $\mathrm{M}$ (1999) Mcl-1 and Bcl-xL are co-regulated by IL-6 in human myeloma cells. Br. J. Haematol. 107: 392-395

25. Catlett-Falcone R, Landowski TH, Oshiro MM, Turkson J, Levitzki A, Savino R Ciliberto G, Moscinski L, Fernandez-Luna JL, Nunez G, Dalton WS and Jove R (1999) Constitutive activation of Stat3 signaling confers resistance to apoptosis in human U266 myeloma cells. Immunity 10: 105-115

26. Tu Y, Renner S, Xu F, Fleishman A, Taylor J, Weisz J, Vescio R, Rettig M Berenson J, Krajewski S, Reed JC and Lictenstein A (1998) BCL-X expression in multiple myeloma: possible indicator of chemoresistance. CancerRes. 58:256 262
27. Xu FH, Sharma S, Gardner A, Tu Y, Raitano A, Sawyers C and Lichtenstein A (1998) Interleukin-6-induced inhibition of multiple myeloma cell apoptosis: support for the hypothesis that protection is mediated via inhibition of the JNK/ SAPK pathway. Blood 92: 241-251

28. Zhang XG, Gaillard JP, Robillard N, Lu ZY, Gu ZJ, Jourdan M, Boiron JM, Bataille $R$ and Klein B (1994) Reproducible obtaining of human myeloma cell lines as a model for tumor stem cell study in human multiple myeloma. Blood 83: 3654 3663

29. Vermes I, Haanen C, Steffens-Nakken Hand Reutelingsperger C (1995)A novel assay for apoptosis. Flow cytometric detection of phosphatidylserine expression on early apoptotic cells using fluorescein labelled Annexin V. J. Immunol. Methods 184: $39-51$

30. Kayalar C, Ord T, Testa MP, Zhong LT and Bredesen DE (1996) Cleavage of actin by interleukin 1 beta-converting enzyme to reverse DNase I inhibition. Proc. Natl. Acad. Sci. USA 93: 2234-2238

31. Knodel M, Kuss AW, Lindemann D, Berberich I and Schimpl A (1999) Reversal of Blimp-1-mediated apoptosis by A1, a member of the Bcl-2 family. Eur. J. Immunol. 29: 2988-2998

32. Lomo J, Smeland EB, Krajewski S, Reed JC and BlomhoffHK (1996) Expression of the bcl-2 homologue mcl-1 correlates with survival of peripheral blood $b$ lymphocytes. Cancer Res. 56: 40-43

33. Moulding DA, Quayle JA, Hart CA and Edwards SW (1998) Mcl-1 expression in human neutrophils: regulation by cytokines and correlation with cell survival. Blood 92: 2495-2502

34. Zhou P, Qian L, Kozopas KM and Craig RW (1997) Mcl-1, a Bcl-2 family member, delays the death of hematopoietic cells under a variety of apoptosis-inducing conditions. Blood 89: 630-643

35. Zhou P, Qian L, Bieszczad CK, Noelle R, Binder M, Levy NB and Craig RW (1998) $\mathrm{Mcl}-1$ in transgenic mice promotes survival in a spectrum of hematopoietic cell types and immortalization in the myeloid lineage. Blood 92: 3226-3239

36. Ogata A, Chauhan D, Teoh G, Treon SP, Urashima M, Schlossman RL and Anderson KC (1997) IL-6 triggers cell growth via the Ras-dependent mitogenactivated protein kinase cascade. J. Immunol. 159: 2212-2221

37. Jelinek DF, Aagaard-Tillery KM, Arendt BK, Arora T, Tschumper RC and Westendorf JJ (1997) Differential human multiple myeloma cell line responsiveness to interferon-alpha. Analysis of transcription factor activation and interleukin 6 receptor expression J. Clin. Invest. 99: 447-456

38. Berger LC, Hawley TS, Lust JA, Goldman SJ and Hawley RG (1994) Tyrosine phosphorylation of JAK/TYK kinases in malignant plasma cell lines growth stimulated by interleukins 6 and 11. Biochem. Biophys. Res. Commun. 202: 596-605

39. Puthier D, Bataille R and Amiot M (1999) IL-6 up-regulates mcl-1 in human myeloma cells through JAK/STAT rather than ras/MAP kinase pathway. Eur. J. Immunol. 29: 3945-3950

40. De Vos J, Jourdan M, Tarte K, Jasmin C and Klein B (2000) JAK2 tyrosine kinase inhibitor tyrphostin AG490 downregulates the mitogen-activated protein kinase (MAPK) and signal transducer and activator of transcription (STAT) pathways and induces apoptosis in myeloma cells. Br. J. Haematol. 109: 823-828

41. Jourdan M, Ferlin M, Legouffe E, Horvathova M, Liautard J, Rossi JF, Wijdenes J, Brochier $\mathrm{J}$ and Klein B (1998) The myeloma cell antigen syndecan-1 is lost by apoptotic myeloma cells. Br. J. Haematol. 100: 637-646 